\title{
IV. 特殊な病態と治療法
}

\section{ICUにおける急性腎障害}

\section{土井 研人 ${ }^{1)}$ 矢作 直樹 ${ }^{1)}$ 南学 正臣 ${ }^{2)}$ 野入 英世 ${ }^{2)}$}

要旨

ICU症例の 30〜 40\% はAKIを呈し，AKIの合併は死亡率やICU滞在期間といったhard outcomeを有意に 悪化させる，循環器疾患あるいは敗血症がAKIの原因あるいは増悪因子であることが多く, CKDはAKI 発症の強いリスク因子である. 急性心筋梗塞や脳卒中と比較してICUにおけるAKIの予後は極めて悪く, 腎 臓内科医と集中治療医が連携してAKI新規治療の研究開発に従事する必要がある.

〔日内会誌 $103 ： 1081 \sim 1087 ， 2014 〕$

Key words 心腎連関, 心臟手術後AKI, 敗血症, critical care nephrology

はじめに

集中治療医学(intensive care medicine/critical care medicine）は, 内科系あるいは外科系の疾 患に由来して生じた, 呼吸, 循環, 腎, 代謝, 脳神経系などの重篤な臟器不全に対して, 強力 かつ集中的な治療により臓器機能を回復させ重 症患者を救命することを目的としている．集中 治療が行われる集中治療室 (intensive care unit : ICU）においては，急性腎障害（acute kidney injury：AKI)が必然的に高頻度に発症すること に加え, AKIが重要な予後規定因子であることが 近年になって認識されつつある.

\section{ICUにおけるAKIの疫学}

2004 年Critical Care誌にRIFLE基準が発表さ れて以降1), RIFLE基準あるいはAKIN基準を用 いて複数のICUコホートにおけるAKIの発症頻度 が報告された．報告によってある程度のバラッ キが認められるものの, 概ね 30〜 40\% のICU 症例がAKIを発症していることが判る（図 1). また, AKIの重症度が高度になるとともに死亡率 が上昇していくことも確認され (図 2), AKI の早期診断と有効な治療介入がICUにおける予後 (死亡率, ICU滞在期間) の改善に貢献しうるこ とが主張されるようになった. AKI発症リスクと しては，年齢と慢性腎蔵病 (chronic kidney disease : CKD）の合併が数多く報告されており,

\footnotetext{
1）東京大学附属病院救急部 - 集中治療部, 2) 同 血液浄化療法部

Acute Kidney Injury : Progress in Diagnosis and Treatments. Topics : IV. Pathophysiology and Treatments;2. Acute kidney injury in intensive care unit.

Kent Doi ${ }^{1)}$, Naoki Yahagi ${ }^{1)}$, Masaomi Nangaku ${ }^{2)}$ and Eisei Noiri2) $:{ }^{1)}$ Department of Emergency and Critical Care Medicine, The University of Tokyo, Japan and ${ }^{2)}$ Department of Hemodialysis and Apheresis, The University of Tokyo, Japan.
} 


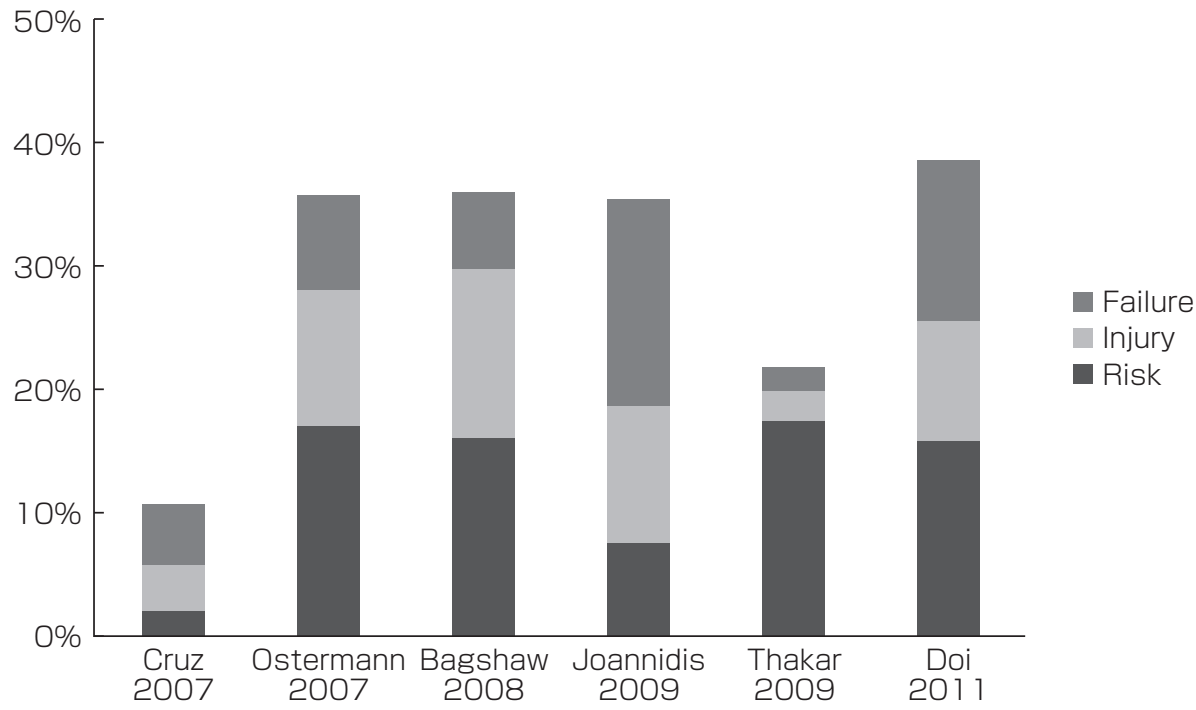

図 1.ICUにおけるAKI発症頻度（\%) と重症度

図 1·図2において示した臨床研究

Cruz DN, et al : Clin J Am Soc Nephrol 2 : 418-425, 2007.

Ostermann M, et al : Crit Care Med 35 : 1837-1843, 2007.

Bagshaw SM, et al : Nephrol Dial Transplant $23: 1569-1574,2008$.

Joannidis M, et al : Intensive Care Med $35:$ 1692-1702, 2009.

Thakar CV, et al : Crit Care Med $37: 2552-2558,2009$.

Doi K, et al : Crit Care Med $39: 2464-2469,2011$.

特に心臓血管手術後AKIでは弁置換手術や手術時 間 (体外循環時間)が，敗血症性AKIでは低アル ブミン血症や肝疾患の合併などが, AKI発症リス クを上昇することが報告されている ${ }^{2}$. また, AKI 症例の死亡率を上昇させる因子としては, 人工 呼吸管理を要する呼吸不全，心不全，肝不全, 血液学的異常などが挙げられ, ICUにおけるAKI が多臓器不全の一分症であることが疫学研究か らも窥われる。

\section{2. 心腎連関におけるAKI}

Coronary/cardiac care unit（CCU）を広義の ICUに含めた場合, 心臟外科術後AKIや急性・慢 性心不全を合併したAKIがICU/CCUにおいては 高頻度に発症する。近年提唱された心腎連関症 候群 (cardiorenal syndrome：CRS)のうち，急
性心不全（低拍出症候群）による腎潅流低下が 主な病態であるType1 CRSと, 慢性心不全急性 増悪 (acute decompensated heart failure: ADHF）に伴う急激な腎機能低下を示すType2 CRSが主にICU/CCUにて認められる(表) ${ }^{3)}$. 特 にType2 CRSにおいては, 左室駆出分画 (ejection fraction : EF) やスワンガンツカテーテルに て測定された心拍出量ではなく, 中心静脈圧が 腎機能の低下と有意な関連を示したことが注目 されている ${ }^{4,5)}$. 中心静脈圧が高い群では血清ク レアチニン濃度（sCre）がより上昇するという 結果は，これまでの過剩気味の体液管理が腎保 護的に作用する（wetがdryよりも腎保護的であ る）という考えを覆すものである. 加えて，複 数の観察研究が体液過剩 (fluid overload) はAKI 症例の予後を有意に悪化させることを報告して いる ${ }^{6,7)}$. 急性呼吸窮迫症候群 (acute respiratory 


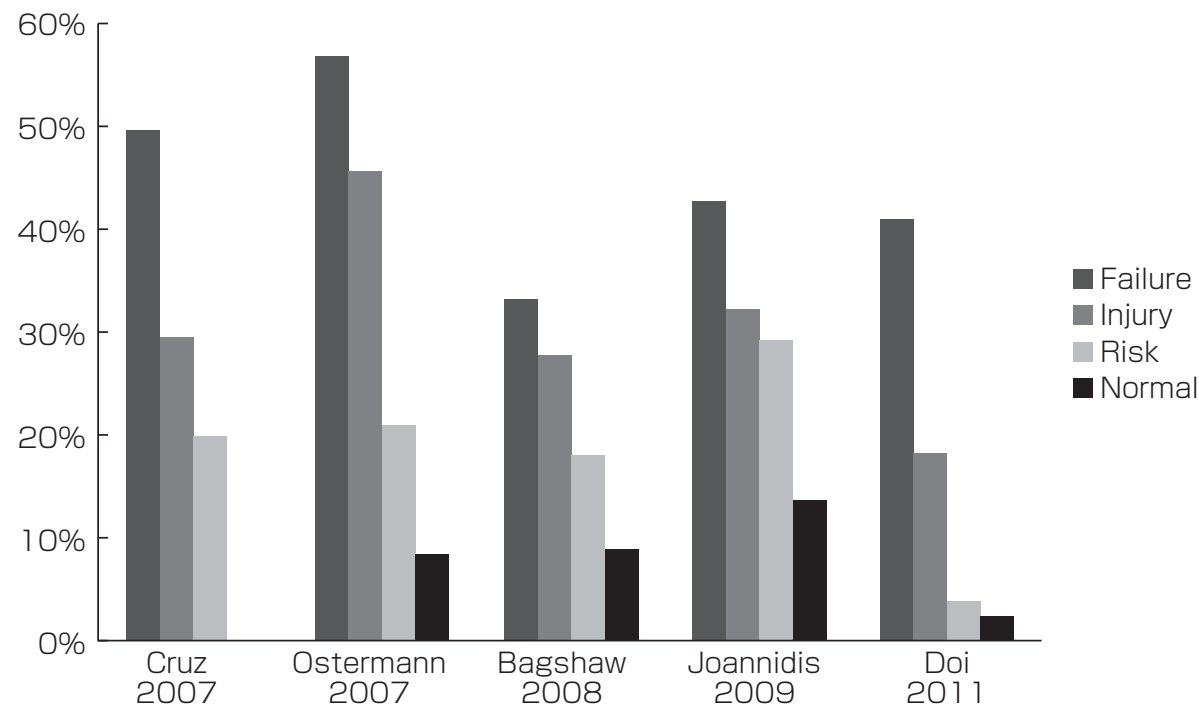

図 2. ICUにおけるAKIの重症度と死亡率（\%)

表. Cardiorenal syndrome (CRS) 分類

\begin{tabular}{l|l|l|l}
\hline \multicolumn{3}{l}{ Cardio-renal syndrome分類 } \\
\hline Type 1 & Acute & Cardio-renal & 心疾患に起因する腎障害 \\
Type 2 & Chronic & Cardio-renal & 心疾患に起因する腎障害 \\
Type 3 & Acute & Reno-cardiac & 腎疾患に起因する心血管障害 \\
Type 4 & Chronic & Reno-cardiac & 腎疾患に起因する心血管障害 \\
Type 5 & Secondary & Systemic disease & 糖尿病・敗血症など \\
\hline
\end{tabular}

distress syndrome : ARDS) 症例を対象として体 液管理戦略をランダム化した介入研究が, NIH/ NHLBIを母体とするARDS Networkにより行わ れたが8), liberal (wet) 群 $(\mathrm{n}=497)$ の方がconservative (dry) 群 $(\mathrm{n}=503)$ と比較して透析を 必要とする頻度が高かった（14\% vs 10\%, p= 0.06).この研究においても wet=腎保護的という 従来の考え方が否定された.

心臟血管手術におけるAKIの発症頻度も高く, 軽度のsCre上昇にとどまる AKI (KDIGO分類で Stage 1, 2 相当)の発症頻度は 10～20\% であり， 血液浄化療法を必要とするAKIは $5 \%$ 程度の症例 に生じるとされている. 軽症AKIにおいても心蔵 手術後生存率を有意に悪化させることが報告さ
れており(図 3),AKINおよびKDIGOによるAKI 診断基準にある「48 時間以内の $0.3 \mathrm{mg} / \mathrm{dl}$ 以上の sCre上昇」は，おもに心臓外科術後 $\mathrm{AKI}$ の臨床 研究結果を強く意識したものである，心臓血管 手術後AKIは術前検査が可能である, insultの程 度（体外循環時間など）と発症時期が明確であ ることから, AKIバイオマーカー研究あるいは AKIに対する薬剤介入研究に適した病態であると 認識されている.

sCre上昇よりも早期に腎障害に反応する新規 AKIバイオマーカーは, 障害を受けた尿細管上皮 細胞から放出されるものであり, これらはネフ ロン構造が破綻してGFRが低下した後に血中に 老廃物として蓄積するクレアチニンの濃度上昇 


\section{トピックス}

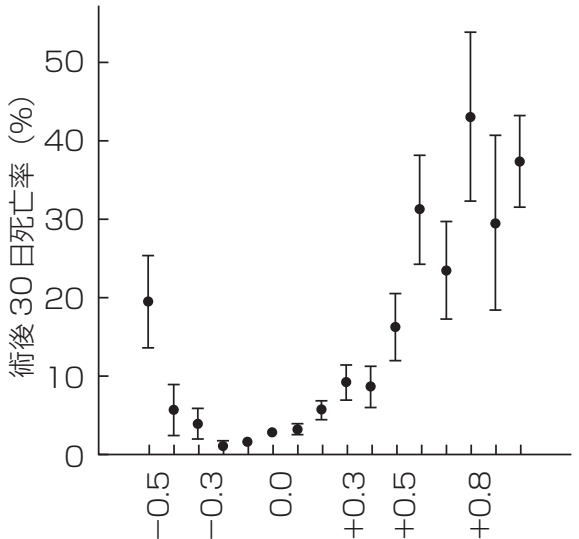

術後 Cre 濃度 $(\mathrm{mg} / \mathrm{dl})$ 変化

図 3. 敗血症性AKIにおける病態

Lassnigg A, et al : J Am Soc Nephrol 15 : 15971605, 2004.より引用

に先行する. 2005 年に米国とカナダの 10 施設で 結成されたTRIBE-AKIコンソーシアムにおいて は, 1,000 人以上の尿・血液サンプルが解析され, 成人・小児心臓手術後AKIにおけるAKIバイオ マーカーのAKI診断能が評価された. その結果, 尿中IL-18, 尿中neutrophil gelatinase-associated lipocalin (NGAL), 血中NGALのreceiver operating characteristics（ROC）曲線下面積がそれ ぞれ $0.74,0.67,0.70$ (成人心蔵手術後AKI) で あったと報告されている ${ }^{9)}$.これらの成績は臨床 パラメータを組み合わせた $\mathrm{AKI}$ 発症予測モデルと ほほ同等であった。

SezaiらはCPB施行下にCABGを施行された非 透析CKD症例において低用量ヒト心房性ナトリ ウム利尿ペプチド (human atrial natriuretic peptide : hANP)の周術期投与が有意に予後を改善 したことを報告しており注目に值する ${ }^{10)}$. また, Westenfelderらは心臓手術後症例に対してヒト 間葉系幹細胞投与により AKIの予後改善を目指し たPhase I研究を行っており, 今後の成果が期待 される11).

\section{3. 敗血症性AKIの病態と治療}

Uchinoらが行った 23 力国54施設のICUにおけ る前向き観察研究によると, AKI症例の約半数に おいて敗血症がその原因であるとされている ${ }^{12}$. 敗血症性AKIの病態生理についての数多くの基礎 研究が行われてきた結果，1）炎症・過剩な免疫 反応の惹起, 2) 虚血・微小循環障害, 3）細胞 死・障害の誘導(ネクローシス, アポトーシス, ミトコンドリア障害),の 3 つの要素が病態形成 に重要な役割を果たしていることが明らかとなっ た.これらのカテゴリーは独立に存在するもの ではなく，敗血症という全身性疾患において相 互に重複しつつAKIの病態形成に寄与している (図 4).

敗血症の病態の中心は過剩な炎症反応であり, 感染に対する防御反応として作用するとともに, いわゆるサイトカインストームとよばれる高サ イトカイン血症・過剩な炎症性メディエーター に起因する蔵器障害が生じると想定されている. 近年, innate immunity（自然免疫）におけるパ ターン認識受容体 (pattern-recognition receptors：PRRs）である，Toll-like受容体（TLR）を 介したシグナルが敗血症性AKIにおいても関与し ていることが報告された ${ }^{13)}$.一方, LPS投与モデ ルよりもより臨床的な敗血症性AKIに近い病態を 再現しているとされる盲腸結禁穿刺 (cecal ligation and puncture : CLP) モデルにおいては14), TLR4 ノックアウトマウスの臟器保護は観察され ず, TLR4 の下流に位置するMyD88 あるいは細 菌DNAを認識するTLR9 を遺伝学的にノックア ウトしたマウスにおいてAKIが軽減した ${ }^{15,16)}$. 臨 床研究においてTAK-242(TLR4 シグナルの抑制) あるいはE5564（エンドトキシン/TLR4 結合阻 害）といった薬剤の開発が中止されたという事 実は, TLR4 以外のPRRをターゲットとした薬剤 開発が敗血症および敗血症性AKIに対して必要で 


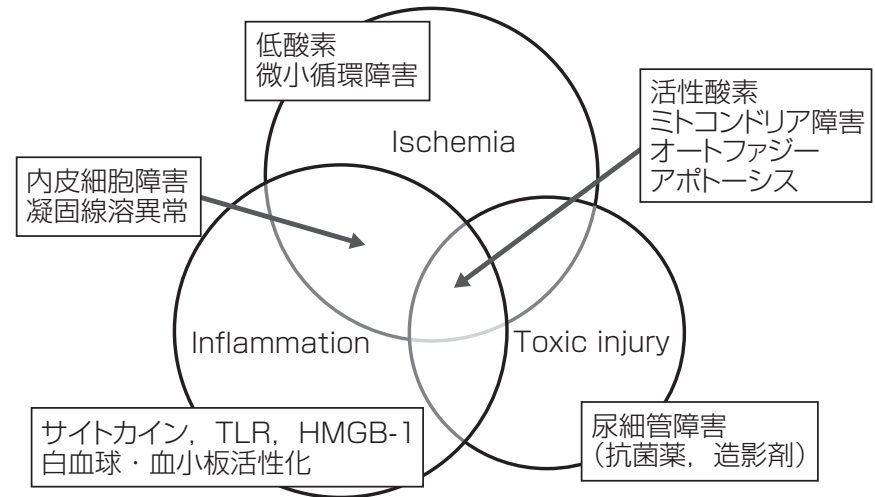

図 4. 敗血症性AKIにおける病態

あることを示唆している.

重症敗血症および敗血症性ショックを来たし た場合には，腎臓における血液潅流圧が減少し て虚血性障害からAKIを呈することは理解しやす い. Bellomoらは羊における細菌持続注入モデル を用いて腎血流量の測定を行った。その結果, 心拍出量が増加し血圧が低下しているwarm ショック（hyperdynamic）においては, 腎血流 量は増加するものの糸球体滤過量が減少してお り, その理由として輸入細動脈の十分な拡張と 輸出細動脈の適切な収縮が得られないことが原 因であるとした ${ }^{17)}$. 尿細管間質における傍尿細管 毛細血管系（peritubular capillary：PTC）にお ける虚血が敗血症性AKIの病態形成に関与してい ることも報告されている. マウス敗血症モデル においては，PTC血流障害による低酸素状態が 尿細管上皮細胞に生じているのみならず18), 血流 低下を来した領域の尿細管上皮細胞から誘導型 NOS由来の活性窒素種 (reactive nitrogen species）産生が観察されている ${ }^{19)}$.

$\mathrm{AKI}$ の病理学的所見として急性尿細管壊死 (acute tubular necrosis : ATN) が広く知られて いるが, 特に敗血症性AKIではヒトおよびげっ歯 類における動物モデルにおいても著明なATN は観察されることはむしろ稀であり ${ }^{20)}$, アポトー シスやオートファジーといった細胞死・障害が
認められる.また, 尿細管上皮細胞は糸球体に おいて濾過された原尿を再吸収する役割を有し， エネルギー代謝はきわめて活発であるため，尿 細管上皮細胞にはミトコンドリアが豊富に存在 する.AKIにおいてはミトコンドリア障害が観察 されるが, マウス敗血症性AKIモデルにおいて, ミトコンドリア生合成のマスター分子であるPeroxisome proliferator-activated receptor gamma coactivator $1-\alpha(\mathrm{PGC}-1 \alpha)$ の腎組織での発現低下 が観察され, さらにPGC-1 $1 \alpha$ ノッアウトマウス はLPSによる敗血症性AKIが増悪した ${ }^{21)}$.

AKIの発症および重症化においてCKDの合併 の有無が最も重要なリスク因子の一つであるこ とが, 疫学的検討にて明らかとなった。敗血症 においてCKDを合併していた場合には高サイト カイン血症の増幅（腎クリアランス低下）など を介して，強い予後悪化因子となることが示さ れている。すなわち，CKDをあらかじめ実験動 物に誘導してその後に敗血症を惹起すると (twohit), vascular endothelial growth factor (VEGF) やHigh mobility group box 1 (HMGB1) の血中 濃度が著しく上昇して, 極めて高い死亡率を呈 する一方，これらの液性因子の作用を阻害する ことで病態の改善が得られている ${ }^{22,23)}$. 実際の臨 床においては, いわゆる acute-on-chronic 腎障害 と呼ばれる複合的な病態が敗血症に生じること 
が高頻度に観察されており, 敗血症性AKIの画期 的な治療戦略開発にはCKDの存在を無視できな いことも認識すべきであろう。

\section{Critical Care Nephrology}

目覚ましい医療技術の進歩により，全身状態 及び循環が極めて不安定な症例においても持続 的腎代替療法 (continuous renal replacement therapy：CRRT）などの血液浄化療法が施行可 能となり, 重症AKI症例のマネージメントが以前 よりも比較的容易となった。このような状況の 中, 慢性透析を中心とした血液浄化療法に携わっ ていた腎蔵内科医（nephrologist）がICUにおけ るCRRTを管理するようになり, 集中治療医 (intensivist）と共同してAKI診療に従事するという 新たな方向性が示され, critical care nephrology という新たな集学的分野multidisciplinary field が提唱されるに至った ${ }^{24)}$.すなわち, ICU領域の 敗血症・多臓器不全に合併したAKIに対する有効 な治療戦略の研究開発およびその実施に際して, 集中治療医intensivistと腎臓内科医nephrologist のより強固な連携とともに，両分野にわたるト レーニングプログラムの確立と人材養成が必須 であるという内容である. しかし，少なくとも 我が国においては未だcritical care nephrology を専攻する研究者・臨床家は数少なく, 急性心 筋梗塞・脳卒中よりも高い死亡率を呈する AKI の治療成績向上には, critical care nephrology という集学的分野を体系的に学習できるプログ ラムの確立が必要不可欠であると筆者は考える.

著者のCOI (conflicts of interest) 開示 : 野入英世 ; 講演料 (旭化成メディカル)

\section{文献}

1) Bellomo R, et al : Acute renal failure - definition, outcome measures, animal models, fluid therapy and information technology needs : the Second International Consensus
Conference of the Acute Dialysis Quality Initiative (ADQI) Group. Crit Care 8: R204-212, 2004.

2) Waikar SS, et al : Diagnosis, epidemiology and outcomes of acute kidney injury. Clin J Am Soc Nephrol 3: 844-861, 2008.

3) Ronco C, et al : Cardiorenal Syndrome. J Am Coll Cardiol $52:$ 1527-1539, 2008.

4) Mullens W, et al: Importance of venous congestion for worsening of renal function in advanced decompensated heart failure. J Am Coll Cardiol 53 : 589-596, 2009.

5) Damman $\mathrm{K}$, et al : Increased central venous pressure is associated with impaired renal function and mortality in a broad spectrum of patients with cardiovascular disease. J Am Coll Cardiol 53 : 582-588, 2009.

6) Payen $D$, et al: A positive fluid balance is associated with a worse outcome in patients with acute renal failure. Crit Care 12:R74, 2008.

7) Bouchard J, et al : Fluid accumulation, survival and recovery of kidney function in critically ill patients with acute kidney injury. Kidney Int 76 : 422-427, 2009.

8) National Heart Lung, and Blood Institute Acute Respiratory Distress Syndrome (ARDS) Clinical Trials Network: Comparison of two fluid-management strategies in acute lung injury. N Engl J Med 354 : 2564-2575, 2006.

9) Parikh CR, et al: Postoperative biomarkers predict acute kidney injury and poor outcomes after adult cardiac surgery. J Am Soc Nephrol 22 : 1748-1757, 2011.

10) Sezai A, et al : Results of low-dose human atrial natriuretic peptide infusion in nondialysis patients with chronic kidney disease undergoing coronary artery bypass grafting : the NU-HIT (Nihon University working group study of low-dose HANP Infusion Therapy during cardiac surgery) trial for CKD. J Am Coll Cardiol 58: 897903, 2011.

11) Tögel FE, Westenfelder $C$ : Kidney protection and regeneration following acute injury:progress through stem cell therapy. Am J Kidney Dis 60 : 1012-1022, 2012.

12) Uchino $S$, et al: Acute renal failure in critically ill patients: a multinational, multicenter study. JAMA 294 : 813-818, 2005.

13) Cunningham PN, et al: Role of Toll-like receptor 4 in endotoxin-induced acute renal failure. J Immunol 172 : 2629-2635, 2004.

14) Doi K, et al: Animal models of sepsis and sepsis-induced kidney injury. J Clin Invest 119 : 2868-2878, 2009.

15) Dear JW, et al : Sepsis-induced organ failure is mediated by different pathways in the kidney and liver:acute renal failure is dependent on MyD88 but not renal cell apoptosis. Kidney Int 69: 832-836, 2006.

16) Yasuda $\mathrm{H}$, et al : Chloroquine and inhibition of Toll-like receptor 9 protect from sepsis-induced acute kidney in- 
jury. Am J Physiol Renal Physiol 294 : F1050-1058, 2008.

17) Bellomo R, et al: Septic acute kidney injury: new concepts. Nephron Exp Nephrol 109 : e95-100, 2008.

18) Yasuda H, et al: Simvastatin improves sepsis-induced mortality and acute kidney injury via renal vascular effects. Kidney Int 69 : 1535-1542, 2006.

19) $\mathrm{Wu} \mathrm{L}$, et al: Evidence for the role of reactive nitrogen species in polymicrobial sepsis-induced renal peritubular capillary dysfunction and tubular injury. J Am Soc Nephrol 18: 1807-1815, 2007.

20) Langenberg $\mathrm{C}$, et al: The histopathology of septic acute kidney injury: a systematic review. Crit Care 12:R38, 2008 .
21) Tran $\mathrm{M}$, et al : PGC-1 $\alpha$ promotes recovery after acute kidney injury during systemic inflammation in mice. J Clin Invest 121 : 4003-4014, 2011.

22) Doi K, et al : Pre-existing renal disease promotes sepsisinduced acute kidney injury and worsens outcome. Kidney Int 74 : 1017-1025, 2008.

23) Leelahavanichkul A, et al : Chronic kidney disease worsens sepsis and sepsis-induced acute kidney injury by releasing High Mobility Group Box Protein-1. Kidney Int 80 : 1198-1211, 2011.

24) Ronco C, Bellomo R : Critical care nephrology : the time has come. Nephrol Dial Transplant 13 : 264-267, 1998. 